\title{
Implementasi Ajaran Catur Marga Yoga dalam Kehidupan Masyarakat Hindu Oleh : Evie
}

\begin{abstract}
Catur Marga are the four ways or manners of the members of a religious community of Hindu for honor and go in the direction of way the God or Ida Sang Hyang Widhi Wasa. The source of teaching Catur Marga are teach in purified literature Bhagawadgita, the main of Trayodhyaya about Karma Marga Yoga, that is one system which content the teaching that the different of teach Subha Karma (good action) with the teach of Asubha Karma (not good action). Karma has two kinds of meaning, that are related to ritual or yajna and karma in meaning action. The second about Bhakti Yoga Marga that is to respectful greeting of God in bring into reality of abstract and resfectful greeting of God in contrete. For example we use nyasa or pratima have the shape statue or mantra. The third about Jnana Marga Yoga that is the way of purified knowledge to go in direction of God. There are two kinds of knowledge. They are jnana (knowledge) and wijnana (everything is know in the knowledge). And the fourth, Raja Marga Yoga that is teach about manner or way of Yoga or medition (th mind concentration) to go in the direction of the God or Ida Sang Hyang Widhi Wasa.
\end{abstract}

\begin{abstract}
Abstrak
Catur Marga adalah empat jalan atau cara umat Hindu untuk menghormati dan menuju ke jalan Tuhan Yang Maha Esa atau Ida Sang Hyang Widhi Wasa. Sumber ajaran Catur Marga ada diajarkan dalam pustaka suci Bhagawadgita, terutama pada Trayodhyaya tentang Karma Marga Yoga yakni sebagai satu sistem yang berisi ajaran yang membedakan antara ajaran Subha Karma (perbuatan baik) dengan ajaran Asubha Karma (perbuatan yang tidak baik). Karma memiliki dua makna yakni karma terkait ritual atau yajna dan karma dalam arti tingkah perbuatan. Kedua, tentang Bhakti Yoga Marga yakni menyembah Tuhan dalam wujud yang abstrak dan menyembah Tuhan dalam wujud yang nyata, misalnya mempergunakan nyasa atau pratima berupa arca atau mantra. Ketiga, tentang Jnana Marga Yoga yakni jalan pengetahuan suci menuju Tuhan Yang Maha Esa, ada dua pengetahuan yaitu Jnana (ilmu pengetahuan) dan Wijnana (serba tahu dalam penetahuan itu). Keempat, Raja Marga Yoga yakni mengajarkan tentang cara atau jalan yoga atau meditasi (konsentrasi pikiran) untuk menuju Tuhan Yang Maha Esa/Ida Sang Hyang Widhi Wasa.
\end{abstract}

\section{PENDAHULUAN}

Catur Marga berasal dari dua kata yaitu Catur dan Marga. Catur berarti empat dan Marga berarti jalan/cara ataupun usaha. Jadi catur marga adalah empat jalan atau cara umat Hindu untuk menghormati dan menuju ke jalan Tuhan Yang Maha Esa/ Ida Sang
Hyang Widhi Wasa. Catur Marga juga sering disebut dengan Catur Yoga Marga. Catur Marga atau Catur Yoga disebutkan adalah empat jalan atau cara umat Hindu untuk menghormati dan mendekatkan diri pada Tuhan Yang Maha Esa atau Ida Sang Hyang Widhi Wasa. 
Sumber ajaran Catur Marga diajarkan dalam pustaka suci Bhagavad Gita, terutama pada trayodhyaya tentang karma yoga/marga yakni sebagai satu sistem yang berisi ajaran yang membedakan antara ajaran subha karma (perbuatan baik) dengan ajaran asubha karma (perbuatan yang tidak baik) yang dibedakan menjadi perbuatan tidak berbuat (akarma) dan wikarma (perbuatan yang keliru).

Karma memiliki dua makna yakni karma terkait ritual atau yajna dan karma dalam arti tingkah perbuatan. Kedua, tentang bhakti yoga marga yakni menyembah Tuhan dalam wujud yang abstrak dan menyembah Tuhan dalam wujud yang nyata, misalnya mempergunakan nyasa atau pratima berupa arca atau mantra. Ketiga, tentang jnana yoga marga yakni jalan pengetahuan suci menuju Tuhan Yang Maha Esa.

Ada dua pengetahuan yaitu jnana (ilmu pengetahuan) dan wijnana (serba tahu dalam penetahuan itu). Keempat, Raja Yoga Marga yakni mengajarkan tentang cara atau jalan yoga atau meditasi (konsentrasi pikiran) untuk menuju Tuhan Yang Maha Esa/Ida Sang Hyang Widhi Wasa.

Dalam Bhagavad Gita, 7:21 disebutkan.

"Yo-yo yàý- yàý tanuý bhaktaá úraddhayàrcitum icchati, tasya tasyà calày úraddày tàm eva vidadhàmy aham"
Terjemahannya adalah.

"Kepercayaan apa pun yang ingin dipeluk seseorang, Aku perlakukan mereka sama dan Ku-berikan berkah yang setimpal supaya ia lebih mantap"

\section{PEMBAHASAN}

\subsection{Bagian-Bagian Catur Yoga 2.1.1 Bhakti Yoga}

Bhakti Yoga adalah proses atau cara mempersatukan atman dengan Brahman dengan berlandaskan atas dasar cinta kasih yang mendalam kepada Ida Sang Hyang Widhi dan segala ciptaan-Nya. Kata bhakti berarti hormat, taat, sujud, menyembah, mempersembahkan, cintah kasih penyerahan diri seutuhnya pada Sang pencipta.

Seorang Bhakta (orang yang menjalani Bhakti marga) dengan sujud dan cinta, menyembah dan berdoa dengan pasrah mempersembahkan jiwa raganya sebagai yadnya kepada Sang Hyang Widhi. Cinta kasih yang mendalam adalah suatu cinta kasih yang bersifat umum dan mendalam yang disebut maitri. Semangat tat twam asi sangat subur dalam hati sanubarinya.

Cinta bhaktinya kepada Hyang Widhi yang sangat mendalam, itu juga dipancarkan kepada semua makhluk baik manusia binatang juga tumbuh-tumbuhan. Dalam doanya selalu menggunakan pernyataan cinta dan kasih sayang dan 
memohon kepada Hyang Widhi agar semua makhluk tanpa kecuali selalu berbahagia dan selalu mendapat anugrah termulia dari Hyang Widhi. Jadi untuk lebih jelasnya seorang bhakta akan selalu berusaha melenyapkan kebenciannya kepada semua makhluk sebaliknya ia selalu berusaha memupuk dan mengembangkan sifat-sifat maitri, karuna, mudita dan upeksa (catur paramita).

Di dalam kitab suci Veda kita jumpai beberapa mantra tentang Bhakti salah satunya adalah:

"Arcata prarcata priyam edhaso Arcata, arcantu putraka uta puram na dhrsnvarcata"

Rgveda VIII.69.8)

(pujalah, pujalah Dia sepenuh hati, Oh cendekiawan, Pujalah Dia. Semogalah semua anak- anak ikut memuja- Nya, teguhlah hati seperti kukuhnya candi dari batu karang untuk memuja keagunganNya).

Terhadap landasan filosofis ajaran Bhakti diatas, Drs. I Gusti Made Ngurah dkk menyatakan pendapatnya: “... bhakti adalah perwujudan cinta yang tulus kepada Tuhan, mengapa harus berbhakti kepada Tuhan karena Tuhan menciptakan alam semesta dengan segala isinya berdasarkan Yajnya." (Ngurah, $2006: 80$ )
Sikap yang paling sederhana dalam kehidupan beragama adalah cinta kasih dan pengabdian yang tulus. Tuhan dipandang sebagai yang paling disayangi, sebagai ibu, bapak, teman, saudara, sebagai orangtua, sebagai tamu, dan sebagai seorang anak. Pada umumnya kita mengenal dua bentuk bhakti yaitu bentuk Aparabhakti dan parabhakti.

a. Apara bhakti artinya tidak utama; jadi apara bhakti artinya cara berbhakti kepada Hyang Widhi yang tidak utama. Apara bhakti dilaksanakan oleh bhakta yang tingkat inteligensi dan kesadaran rohaninya kurang atau sedang-sedang saja. Aparabhakti, yaitu pemujaan atau persembahan dan kebaktian dengan berbagai permohonan dan permohonan itu adalah wajar mengingat keterbatasan pengetahuan kita tentang hakekat bhakti.

b. Para artinya utama; jadi para bhakti artinya cara berbhakti kepada Hyang Widhi yang utama. Para bhakti dilaksanakan oleh bhakta yang tingkat inteligensi dan kesadaran rohaninya tinggi. Parabhakti adalah bhakti berupa penyerahan diri yang setulusnya. Penyerahan diri kepada- Nya bukanlah dalam pengertian pasif tidak mau melakukan berbagai aktivitas, tetapi aktif dan dengan keyakinan bahwa bila bekerja 
dengan baik dan tulus maka akan memperoleh pahala yang baik pula. Kita tidak boleh mendoakan seseorang untuk memperoleh kecelakaan dan sejenisnya. Drs. I Gusti Made Ngurah dkk berpendapat:" bahwa Tuhan yang Maha Esa adalah ibu dan bapa kita , seperti kita meminta sesuatu pada kedua orang tua kita tidak semua permintaan dapat terpenuhi. Demikianlah bila kita memohon kepada Tuhan Yang Maha Esa. Sesungguhnya kita sering mendapat karunia- Nya berupa kesejahteraan, kegembiraan atau kebahagiaan, tetapi bila kita lalai, maka sekali waktu cobaan dan penderitaan yang kita terima. Walaupun itu cobaan dan penderitaan, itupun sesungguhnya sebuah karunia, kita harus mensyukuri agar kita segera mawas diri, memperbaiki kesalahan atau kelalaian kita." (Ngurah, $2006: 83$ )

Dalam meningkatkan kualitas bhakti kita kepada sang Hyang Widi ada beberapa jenis bentuk bhakti yang disebut Bhavabhakti, sebagai berikut:

1. Santabhava, yaitu sikap bhakti seperti bhakti atau hormat seorang anak terhadap ibu dan bapaknya.

2. Sakhyabava, yaitu bentuk bhakti yang meyakini Hyang Widi, manifestasiNya, Istadevata atau Avatara- Nya sebagai sahabat yang sangat akrab dan selalu memberikan perlindungan dari pertolongan pada saat yang diperlukan.

3. Dasyabhava, yaitu bhakti atau pelayanan kepada Tuhan Yang Maha Esa seperti sikap seorang hamba kepada majikannya.

4. Vatsalyabhava, yaitu sikap bhakti seorang penyembah memandang Tuhan Yang Maha Esa seperti anaknya sendiri.

5. Kantabhava, yaitu sikap bhakti seorang istri terhadap suami tercinta.

6. Maduryabhava, yaitu bentuk bhakti sebagai cinta yang amat mendalam dan tulus dari seorang bhakta kepada Tuhan Yang Maha Esa. Secara lahiriah bentukbentuk di Indonesia sama halnya dengan di India, umat mewujudkannya melalui pembangunan berbagai Pura ( mandir), mempersembahkan berbagai sesaji (naivedya), mempersembahkan kidung (bhajan), gamelan, tari- tarian, dan sebagainya.

Ciri-ciri seorang Bhakti Marga yaitu :

1. Keinginan untuk berkorban.

2.Keinginan untuk bertemu

Tuhan senang bila engkau menolong dan melayani sesama manusia (pengabdian / dharmabakti). Kitab-kitab suci telah menetapkan 9 jalan bhakti, yaitu : 
- Mendengarkan kisah-kisah Tuhan (shravanam)

- Menyanyikan kemuliaan Tuhan (kirtanam)

- Mengingat Nama-Nama Tuhan ( Vishnusmaranam)

- Melayani kaki Tuhan yang suci (padasevanam)

- Pemujaan (archanam)

- Sembah sujud (vandanam)

- Pengabdian (dasyam)

- Persahabatan (sneham)

- Pasrah / penyerahan diri kepada Tuhan sepenuhnya (atmanivedanam)

\section{Jnana Yoga}

Jnana artinya kebijaksanaan filsafat (pengetahuan). Yoga berasal dari urat kata Yuj artinya menghubungkan diri. Jadi jnana yoga artinya mempersatukan jiwatman dengan paramatman yang dicapai dengan jalan mempelajari dan mengamalkan ilmu pengetahuan baik science maupun spiritual, seperti hakekat kebenaran tentang Brahman, Atman. Dengan pemanfaatan ilmu pengetahuan yang sejati akan mampu membebaskan diri dari ikatan-ikatan keduniawian. Ada tiga hal yang penting dalam hal ini yaitu kebulatan pikiran, pembatasan pada kehidupan sendiri dan keadaan jiwa yang seimbang atau tenang maupun pandangan yang kokoh tentram damai. Ketiga hal tersebut di atas merupakan dhyana yoga. Untuk tercapainya perlu dibantu dengan abhyasa yaitu latihanlatihan dan vairagya yaitu keadaan tidak mengaktifkan diri. Adapun kekuatan pikiran kita lakukan di dalam hal kita berbuat saja, pikiran harus kita pusatkan kepadanya.

Ada enam macam (satsampat), yaitu:

1. Ketenangan (sama)

2. Pengekangan (dama)

3. Penolakan (uparati), ketabahan (titiksa)

4. Keyakinan (sraddha)

5. Konsentrasi (samadhana)

6. Kerinduan yang sangat akan pembebasan (mumuksutva).

Ada tujuh tahapan dari Jñana atau pengetahuan, yaitu;

1. Aspirasi pada kebenaran (subhecha)

2. Pencarian filosofis (vicarana)

3. Penghalusan pikiran (tanumanasi)

4. Pencapaian sinar (sattwatti)

5. Pemisahan batin (asamsakti)

6. Penglihatan spiritual(padarthabhawana)

7. Kebebasan tertinggi (turiya).

\subsubsection{Karma Yoga}

Karma Marga adalah cara/ajaran untuk mencapai moksa dengan jalan ditekankan 
pada pengabdian yang berwujud kerja tanpa

pamrih untuk kepentingan diri sendiri.

Hidup manusia di dunia ini dibelenggu oleh hukum kerja, seperti disebutkan dalam Bhagavadgita III.5 ada disebutkan:

Na hi kascit ksanam api

Jatu tisthati akarma-krt,

Karyate hy avasah karma,

Sarvah prakrti-jair gunaih

Terjemahan:

Walaupun untuk sesaat juga tidak seorang pun untuk tidak berbuat karena setiap manusia dibuat tidak berdaya.

Bhagavadgita III.8 menegaskan lagi sebagai berikut:

Niyatam kuru karma tvam

Karma jyayo hyakarmanah

Sarira-yatrapi ca te na

Prasidhyed akarmanah

Terjemahannya:

Bekerjalah seperti yang telah ditentukan sebab berbuat lebih baik daripada tidak berbuat dan bahkan tubuh pun tidak terpelihara tanpa berkarya.

Kenyataannya memanglah benar demikian, tidak ada orang yang bisa menghindari diri untuk tidak bekerja walaupun di waktu tidur, karena jantung selalu berdetak, darah selalu mengalir dan nafas selalu bekerja walaupun kita tidak menyadari. Sebab berpikir saja sudah melahirkan karma lebih-lebih kalau buah pikirannya itu dituangkan dalam bentuk upacara atau perbuatan maka sempurnalah karma yang dibuatnya.

\section{Karma Yoga sebagai Etos Kerja Umat Hindu}

Berbicara tentang karma adalah berbicara tentang tindakan, kerja. Dan berbicara tentang Karma Yoga adalah berbicara tentang cara tindakan kerja. Janganlah orang terpaku kepada pemeo yang mengatakan karma selalu dikaitkan dengan hukum karma atau karmaphala, yaitu sebagai suratan nasib. Terutama keada orang-orang yang tidak beruntung dalam melaksanakan kerja, lalu dikatakan: "Nah, itulah karmaphala-mu, suratan nasib-mu!". Ini tentu tidak betul. Jangan sekali-kali pemeo ini dijadikan pola pikir yang mengidentikkan nasib jelek, frustasi, putus asa, kurang mampu sama dengan karmaphala, hukuman terhadap tindakan kerja dimasa-masa lampau. Karmaphala sesungguhnya adalah positif dan objektif. Sebab dia didasarkan atas Karma Yoga, dan Karma Yoga adalah etos kerja. Ingatlah petunjuk yang diberikan Bhagawadgita: "Bekerjalah seperti yang telah ditentukkan, sebab bekerja lebih baik dari tak kerja, kalau engkau tidak bekerja, hidup sehari-hari pun tidak mungkin". (III.8)

Swami Vivekananda pernah mengatakan, karma adalah kerja, dan tujuan kerja adalah mencapai ilmu pengetahuan lewat Karma Yoga. Lebih jauh Swami Vivekananda mengungkapkan sebagai contoh Sir Isaac Newton (1642-1727), karena bekerja keras lalu menemukan "daya tarik berat bumi" (gravitation). Ia belajar dari kerja, ia memperoleh ilmu pengetahuan karena kerja. 
Dengan ilmu pengetahuan ini ia "menemukan" gravitasi, padahal gravitasi sebelum Newton menemukannya memang sudah ada disitu sebagai milik alam semesta ini. Demikian pula Galileo Galilei (15641642) karena kerja keras memperoleh ilmu pengetahuan lalu menciptakan teleskop untuk pertama kalinya mengobservasi astronomi, padahal sebelum ia menemukan teleskop astronomin sudah ada milik alam semesta. Thomas Alva Edison(1847-1931) karena bekerja keras memperoleh ilmu pengetahuan lalu menciptakan bola lampu listrik padahal aliran listrik sebelum Edison menciptakan bola lampu listrik, listrik sudah ada milik alam semesta ini. Suami-istri Pierre Curies(1859-1906) berkat kerja keras mencapai ilmu pengetahuan lalu "menemukan" radium, yang walaupun mereka sebelum menemukannya sudah ada milik alam semesta. Demikianlah karma, lewat Karma Yoga, merupakan etos kerja menjadikan karmaphala hal-hal yang positif dan objektif.

Semua ilmu pengetahuan adalah hasil kerja otak dan pikiran manusia. Dan "perpustakaan" ilmu pengetahuan bertahta dalam otak dan pikiran manusia. Seperti halnya Sir Isaac Newton memperhatikan dan mempelajari lewat kerja "jatuhnya sebuah apel dari pohon" lalu menemukan hokum gravitasi , gaya tarik bumi, yang kita kenal sekarang. Jadi kesimpulannya adalah kita bekerja, kita mengobservasi, kita pelajari, kita menemukan dan kita simpulkan: tujuan kerja adalah mencapai ilmu pengetahuan. Ilmu pengetahuan, baik itu secular maupun spiritual bertahta pada otak dan pikiran manusia. Makin tekun seseorang bekerja, makin dalam ia mempelajari hasil kerjanya, makin tinggi ilmu pengetahuan yang diperolehnya, makin sempurna segala sesuatunya yang dia"ketemukan" dalam pengembaraan etos kerja untuk mencapai ilmu pengetahuan. Inilah konsep kerja dan ilmu pengetahuan menurut Hindu, yang merupakan etos kerja, hasil karma lewat Karma Yoga.

Mari kita simak makna karma dan Karma Yoga itu. Orang bekerja dengan berbagai motivasi. Memang sesungguhnya tidak ada kerja tanpa motivasi. Seseorang bekerja denga motivasi agar menjadi orang ternama dan dia betul-betul berusaha untuk itu. Yang lain ingin kekayaan dan harta benda yang sebanyak-banyaknya, dia bekerja untuk uang. Yang lain lagi menginginkan kekuasaan dan dia bekerja keras demi kekuasaan tersebut. Demikian yang lainpula ingin mencapai surga dan dia berusaha ekstra berat untuk itu. Tentunya ada juga untuk titel dan nama yang harum, 
bangsawan terhornat, dan bekerja demi pekerjaan itu sendiri. Mereka bekerja, umumnya rakyat jelata, demi pekerjaan itu sendiri, bukan untuk harumnya nama, bukan demi harta kekayaan, bukan kekuasaan dan bukan pula mencapai surga. Mereka bekerja karena kerja itu menghasilkan yang baik untuk orang banyak, untuk mereka yang miskin dan terlantar. Mereka bekerja karena dengan bekerja demikian orang lain merasa terbantu, dengan bekerja demikian dirasakan sebagai perbuatan yang baik penuh kemanusiaan. Apapun motivasnya, kerja harus dilaksanakan. Walaupun kerja yang paling rendah dalam bentuk kasar tidaklah patut dicemooh dan dihinakan. Orang hendaknya berfikir secara positif bahwa kerja memiliki motivasi yang lebih baik dan lebih tinggi derajatnya sebagai persepsi yang mulia. Dengan kata lain, motivasi bukanlah tujuan akhir melainkan jembatan untuk mencapai kerja yang lebih baik. Upaya meningkatkan kerja yang lebih baik inilah melahirkan ilmu pengetahuan tentang kerja itu sendiri yang memiliki motivasi kemuliaan. Inilah hakikat kerja lewat titian Karma Yoga yang diajarkan oleh Bhagawadgita: “Orang tidak akan mencapai kebebasan, karena diam tiada bekerja, juga ia takkan mencapai kesempurnaan karena menghindari kegiatan kerja", lebih jauh “tidak seorang pun tidak bekerja, walaupun untuk sesaat jua, karena dengan tiada berdaya manusia, dibuat bertindak oleh hokum alaam "(III.4\&5).

Karma Yoga adalah cara atau jalan menciptakan etos kerja bagi umat Hindu. Kerja yang bagaimana? Sloka-sloka kitab suci yang telah diwahyukan sejak zaman paling purba memberi petunjuka apa makna kerja dan bagaimana kerja harus dilaksanakan. Dan para Maharishi kita dari abad keabad berupaya mengkaji ulang dan memberi makna pada etos kerja menurut zamannya. Mereka yang arif bijaksana ini mengisyaratkan bahwasanya kerja, tindakan (action) adalah hukum alam semesta, memberi petunjuk kepada Arjuna, karma adalah kerja positif, konstruktif secara gambelang. Dan analisis yang dipaparkan adalah berwatak ilmiah fondmental dan universa. Dan Krisnha juga menolak hidup tunakerja: Akarma (Inactivity, Actionlessness). Dalam kaitan pemindahan penduduk lewat transmigrasi penduduk Bali yang mayoritas adalah umat Hindu, dan program mengentaskan kemiskinan di tempat asal dengan maksud agar di tempat baru mereka tidak miskin lagi, seyogyanya pola piker rekayasa yang dianut adalah konsep etos kerja yang di isyaratkan Krisnha kepada Arjuna. Etos 
kerja ini berlandaskan aspek-aspek karma, yaitu kerja positif dan konsrtuktif yang dipacu oleh minat, motivasi, harapan dan kepastian bagi mereka yang ditransmigrasikan, yang dientaskan kemiskinannya, bukan untuk merekamereka pejabat dan penguasa. Semua ini dilaksanakan lewat Karma Yoga, jalan kerja, cara kerja. Istilah yoga, terkait dengan istilah Karma Yoga, hendaknya dipahami secara betul. Yoga disini bermakna suatu synthesis antara lain spiritual dan pengetahuan benda-benda materi (spirit and matter). Keseimbangan antara spiritualitas dan materialitas merupakan hasil cemerlang yoga, yang dalam hal ini adalah dimaksudkan Karma Yoga. Keseimbangan ini sering dikaitkan dengan doktrin Trihita Karana. Hidup serasi, selaras, seimbang, diantara semua makhluk hidup, alam semesta dan Hyang Widhi seru sekalian alam. Untuk mencapainya, dengan cara Karma Yoga.

\section{Bekerja sebagai Keharusan}

Istilah bekerja dalam buku ini tidak hanya dikenakan pada bekerja untuk mendapatkan uang atau mencari nafkah melainkan juga untuk kegiatan yang lain yang tidak mesti mendapatkan uang. Kegiatan-kegiatan yang dimaksud antara lain adalah kerja bakti, membantu orang punya hajat, menengok orang sakit, melayat orang meninggal, mengerjakan segala macam tugas dalam rumah tangga, menyiapkan upacara, melaksanakan upacara agama dan sebagainya. Jadi yang dimaksud dengan bekerja dalah semua kegiatan manusia yang patut mereka kerjakan dalam kehidupan. Jenis-jenis perkerjaan ini pulalah yang menjadi cakupan Karma Yoga yang di bahas dalam tulisan ini. Apa dasarnya bekerja itu merupakan suatu keharusan bagi manusia? Dalam kitab Bhagawadgita disebutkan bahwa "jika Aku (Tuhan) berhenti bekerja dunia ini akan hancur lebur dan Aku jadi pecipta keruntuhan memusnahkan manusia ini semua (Pendit,1986). Tuhan Yang Maha Esa sebagai pencipta adalah merupakan panutan manusia sebagai mahkluk ciptaannya oleh sebab itu apapun yang dilakukan Tuhan harus diikuti oleh manusia dalam hal ini Tuhan tidak pernah berhenti bekerja. Dikatakan lebih lanjut sedetik saja Tuhan tidak berkerja dunia ini akan kiamat oleh sebab itu merupakan kewajiban bagi manusia untuk bekerja. Uraian di atas adalah merupakan hukum ketuhanan atau agama. Bagaimana kalau bekerja itu ditinjau dari hukum keduniawian? Apakah bekerja juga merupakan keharusan bagi umat manusia? Menitis atau menjadi manusia di dunia 
adalah menjalani hidup sebagai manusia di alam fana ini. Sebagai manusia yang bekali Tuhan piranti khusus seperti pikiran, perasaan, cita-cita, dan kata hati, seharusnya berperilaku yang berbeda dengan binatang yang hanya dikuasai oleh insting untuk melaksanakan kehidupannya. Manusia dengan piranti khusus itu seharusnya memanfaatkan piranti itu untuk meningkatkan hidup dan kehidupan manusia itu sendiri dengan cara ini pula timbul budaya dalam kehidupan manusia, sesuatu yang membuat manusia hidup lebih enak, lebih makmur, lebih bahagia walaupun bisa juga menimbulkan kesengsaraan sebagai umat manusia, manakala budaya itu disalahgunakan ke arah yang negatif. Jadi bekerja menurut hukum keduniawian adalah wajib. Sebab tanpa bekerja manusia tidak akan bisa mengembangkan budayanya, yang berakibat hidupnya tetap dikendalikan insting saja, seperti halnya dengan kehidupan di zaman purbakala. Selain itu, bila manusia tidak memanfaatkan piranti khusus yang di berikan Tuhan seperti di atas, mereka dapat di pandang melecehkan pemberian Tuhan. Sementara itu perbuatan melecehkan Tuhan adalah suatu dosa. Kita yakin bahwa tidak ada orang yang ingin berbuat dosa. Karena itu bekerja menggunakan piranti khusus merupakan suatu keharusan. Diatas sudah dijelaskan bahwa bekerja untuk meningkatkan kebudayaan adalah sebagian besar untuk meningkatkan hidup dan kehidupan manusia, namun jika budaya itu disalahgunakan dapat medatangkan bencana bagi umat manusia. Sebagai contoh adalah memanfaatkan ekonomi moneter yang lemah untuk memperkaya diri dengan membeli dan menyimpan dolar di luar negeri. Contoh yang lain menciptakan berbagai bentuk narkotika untuk kepentingan sekelompok orang. Memproduksi dan menggunakan alat-alat terntentu yang dapat merusak lapisan ozon membuat bom kuman atau bom nuklir untuk memusnahkan musuh secara besar-besaran, dan sebagainya. Dari contoh di atas dapat dipahami bahwa kewajiban manusia bekerja untuk meningkatkan budaya, kendaknya diperhatikan dan diawasi agar tidak mengarah kepada hal-hal yang negatif. Lebih-lebih dalam menghadapi era globalisasi ini hendaklah budaya kerja sama, kompetisi sehat dan upaya mempertahankan identitas diri di tingkatkan. Inilah arah yang harus dituju dalam bekerja, disamping upaya meningkatkan profesi kita masing-masing. Dengan cara ini kita berharap tidak akan terjepit oleh negara-negara lain, terutama yang sudah maju, dalam arus globalisasi ini. 
Selanjutnya tentang contoh mengharapkan imbalan tertentu antara lain ialah ingin mendapat nilai baik, ingin mendapat juara, ingin cepat lulus, ingin diterima disekolah atau perguruan tinggi yang baik tapi tidak mahal, dan sebagainya. Pekerjaan yang dilakukan yang didorong oleh keinginankeinginan seperti ini dapat saja dilakukan tetapi tidak selalu keinginan itu terkabulkan. Sebab sukses suatu hasil pekerjaan yang dicapai tidak hanya ditentukan oleh kerajinan semata, melainkan juga ditentukan oleh tingkat kemampuan mental seseorang serta bakatnya. Kalau keinginan tidak tercapai mungkin anak atau remaja ini akan setres atau menderita bathin. Ini pula sebabnya mengapa Wikarma jenis ini juga tidak dibenarkan oleh agama. Agama menginginkan seseorang bekerja dengan hasil yang wajar sesuai dengan kerajinan, kemampuan dan bakatnya. Namun memilih sekolah atau jurusan yang sesuai dengan minat dan bakat anak atau remaja tidak dikategorikan sebagai Wikarma. Sebab pemilihan ini sudah bersifat alamiah, yaitu sesuai dengan keadaan seseorang. Yang termasuk Wikarma dalam kaitan dengan pemilihan ini adalah manakala orang tua atau anak atau remaja itu sendiri memilih sekolah atau jurusan yang nantinya setelah lulus diperkirakan akan mendapatkan hasil atau nafkah yang besar. Pemilihan seperti ini termasuk memperkosa kewajaran anak atau remaja itu. Sebab itu, cara kerja seperti ini dikatagorikan sebagai Wikarma. Bagaimana halnya dengan orang-orang dewasa yang sebagian besar bekerja mengharapkan imbalan tertentu serta memilih pekerjaan yang ringan tetapi mendapat hasil yang besar. Malah sering kali mereka memohon kepada Tuhan agar niatnya terkabul. Perkara mengharap imbalan, memilih pekerjaan, dan memohon dapat saja dilakukan oleh seseorang. Namun apapun yang dikerjakan akan mendapatkan dampak tertentu. Dampak itu sudah diatur dalam hukum karma. Dari contoh-contoh diatas tampaknya hanya pekerjaan yang wajar saja berkenan di hati Tuhan. Pekerjaan lain yang tidak wajar yang disebut Wikarma pada umumnya akan memberi dampak yang tidak menyenangkan. Sebab itu kita harus menghindari pekerjaan-pekerjaan yang bersifat Wikarma.

Kini sampailah waktunya kita membahas pekerjaan yang bersifat Subha Karma atau cara bekerja atau sikap bekerja yang baik atau perilaku yang baik dalam bekerja. Subha Karma adalah menerima setiap tugas yang dibebankan kepada kita. Hal ini berlaku bagi siswa disekolah, pada remaja di perguruan tinggi, dan orang-orang dewasa di 
tempat bekerja. Kalau pekerjaan itu dirasakan terlalu berat, boleh saja didiskusikan antara yang memberi tugas dengan yang menerima tugas atau antar anggota yang melaksanakan tugas. Dari hasil diskusi ini biasanya akan di dapatkan jalan keluar sehingga pekerjaan akan menjadi lebih ringan.

Melaksanakan tugas secara Subha Karma adalah bekerja dengan sikap bebas tanpa tekanan, tenang, gembira, bersungguhsungguh, berusaha mencari jalan keluar dalam mengatasi setiap rintangan, dan berupaya agar pekerjaan itu dapat diselesaikan dengan sukses. Jadi hati mereka yang bekerja seperti ini hanya terpaku pada pekerjaan itu saja, pikirannya hanya dipusatkan pada penyelesaian pekerjaan itu. Tidak pikiran dan niat lain selain pada pekerjaan itu. Perilaku bekerja seperti inilah yang disebut Subha Karma. Perilaku bekerja seperti ini pula yang disebut sembahyang melalui bekerja atau mendekatkan diri kepada Tuhan Yang Maha Esa melaui bekerja. Inilah yang disebut Karma Yoga.

Umat Hindu pada setiap melakukan pekerjaannya hendaklah memakai prinsip Karma Yoga ini, sebab perilaku seperti ini yang di kehendaki oleh Tuhan. Pekerjaan yang dikerjakan banyak ragamnya.mulai dari pekerjaan dirumah, di masyarakat, di tempat-tempat mencari nafkah, sampai dengan di pura atau di tempat lain ketika mengadakan upacara keagamaan. Mengerjakan tugas rumah tangga oleh para ibu misalnya haruslah dilakukan secara tulus hati, riang, menyenangkan, dan mendidik anak-anak dengan antusias sebab suasana keluarga merupakan daras pembinaan generasi muda dalam rangka menyiapkan SDM yang berkualitas untuk kebutuhan pembangunan bangsa serta kemampuan berkompetisi dalam era globalisasi ini.

Dalam melaksanakan kegiatan-kegiatan keagamaan pun prinsip Karma Yoga harus dilaksanakan, artinya mulai dari merencanakan, mempersiapkan, sampai dengan melaksanakan, setiap upacara harus dilakukan dengan bersungguh-sungguh, tulus hati dan dengan pikran serta perasaan yang jernih. Dilarang melakukan upacara karena terpaksa, sebab malu pada orang lain, karena ingin mendapat pujian, atau mencari kesempatan tertentu untuk keuntungan diri sendiri, dan perilaku-perilaku yang lain yang tidak sejalan dengan maksud upacara.

Prinsip bekerja yang telah diuraikan diatas, ditayangkan dan diperdengarkan pada setiap film Ramayana dimulai. Suatu film yang 
menggambarkan ajaran Agama Hindu yang baru-baru ini diputar dalam tayangan televisi. Setiap tayangan dimulai dengan kalimat-kalimat seperti berikut (1) lakukan kewajibanmu jangan harapkan imbalnnya, (2) jangan lakukan sesuatu dengan harapan akan dapat imbalan, (3) jangan lupa akan kewajibanmu. Kalimat pertama mengacu kepada Subha Karma, yaitu Karma Yoga, kalimat kedua mengacu kepada Wikarma sebagai perilaku bekerja yang tidak benar, dan kalimat ketiga mengacu kepada Akarma atau tidak bekerja. Film itu hanya menyuruh melakukan yang pertama saja yaitu Subha Karma atau Karma Yoga dan melarang melakukan yang kedua dan ketiga yang bersifat Asubha Karma.

\subsubsection{Raja Yoga}

Raja yoga adalah suatu jalan mistik (rohani) untuk mencapai kelepasan atau moksa. Melalui raja marga yoga seseorang akan lebih cepat mencapai moksa, tetapi tantangan yang dihadapinya pun lebih berat, orang yang mencapai moksa dengan jalan ini diwajibkan mempunyai seorang guru kerohanian yang sempurna untuk dapat menuntun dirinya ke arah tersebut. Adapun tiga jalan pelaksanaan yang ditempuh oleh para raja yogin yaitu melakukan tapa, brata, yoga, Samadhi. Tapa dan brata merupakan suatu latihan untuk mengendalikan emosi atau nafsu yang ada dalam diri kita kearah yang positif sesuai dengan petunjuk ajaran kitab suci. Sedangkan yoga dan Samadhi adalah latihan untuk dapat menyatukan atman dengan Brahman dengan melakukan meditasi atau pemusatan pikiran.

Seorang raja yoga akan dapat menghubungkan dirinya dengan kekuatan rohani melalui astangga yoga yaitu delapan tahapan yoga untuk mencapai moksa. Astangga yoga diajarkan oleh Maharsi Patanjalai dalam bukunya yang disebut yoga sutra patanjali. Adapun bagian-bagian dari astangga yoga adalah sebagai berikut:

1. Yama yaitu suatu bentuk larangan yang harus dilakukan oleh seseorang dari segi jasmani yaitu :

- Dilarang membunuh (ahimsa)

- Dilarang berbohong (satya)

- Pantang menginginkan sesuatu yang bukan miliknya (asteya)

- Pantang melakukan hubungan seksual (brahmacari)

- Tidak menerima pemberian dari orang lain (aparigraha)

2. Nyama yaitu pengendalian diri yang bersifat rohani yaitu :

- Sauca (tetap suci lahir bhatin) 
- Santosa (selalu puas dengan apa yang datang)

- Swadhyaya (mempelajari kitabkitab keagamaan)

- Iswara pranidhana (selalu bhakti kepada Tuhan)

- Tapa (tahan uji)

3. Asana yaitu sikap duduk yang menyenangkan, teratur dan disiplin

4. Pranayama yaitu mengatur pernafasan sehingga menjadi sempurna melalui tiga jalan yaitu :

- Puraka (menarik nafas)

- Kumbhaka (menahan nafas)

- Recaka (mengeluarkan nafas)

5. Pratyahara yaitu mengontrol dan mengendalikan indriya dari ikatan obyeknya, sehingga orang dapat melihat hal-hal suci

6. Dharana yaitu usaha-usaha untuk menyatukan pikiran dengan sasaran yang diinginkan

7. Dhyna yaitu pemusatan pikiran yang tenang, tidak tergoyahkan kepada suatu obyek. Dhyna dapat dilakukan terhadap Ista Dewata

8. Samadhi yaitu penyatuan atman, Bila seseorang melakukan latihan yoga dengan teratur dan sungguh-sungguh ia akan dapat menerima getaran-getaran suci dan wahyu Tuhan. Keempat jalan untuk pencapaian moksa itu sesungguhnya memiliki kekuatan yang sama bila dilakukan dengan sungguhsungguh. Setiap orang akan memilih kecenderungan memilih jalan-jalan tersebut, maka itu setiap orang memiliki jalan mencapai moksa bervariasi.

Moksa sebagai tujuan hidup spiritual bukanlah merupakan suatu janji yang hampa melainkan merupakan suatu keyakinan yang berakhir dengan kenyataan. Kenyataan dalam dunia batin merupakan alam super transcendental yang hanya dapat dibuktikan berdasarkan instuisi yang dalam. Moksa merupakan suatu yang tidak dapat dibantah kebenarannya, karena demikianlah yang dijelaskan oleh kitab suci. Oleh sebab itu marilah kita melatih diri untuk melaksanakan ajaran astangga yoga dengan tuntunan seorang guru yang telah memiliki kemampuan didalam hal tersebut.

Keempat jalan (marga) itu dapat dilakukan diberbagai tempat dan waktu sesuai kemampuan seseorang dan keempatnya tidak dapat dipisahkan karena dalam prakteknya saling berkaitan. Misalnya sembahyang , keempat cara (marga) itu dapat diamalkan sekaligus yaitu: 
a. Rasa hormat atau berserah merupakan wujud bhakti marga.

b. Menyiapkan sarana kebhaktian merupakan wujud karma marga.

c. Pemahaman tentang sembahyang merupakan wujud jnana marga.

d. Duduk tegak-tenang-konsentrasi merupakan wu jud raja marga.

Jika direnungkan dan diperhatikan maka sesungguhnya pengamalan agama Hindu sangat mudah, praktis dan lues. Keluesan itu disebabkan karena agama Hindu dapat dilaksanakan :

Dengan mempraktekan Catur Marga oleh seluruh umat tanpa terkecuali disegala tempat, waktu dan keadaan tidak harus dengan materi sesuai dengan kemampuan umat sesuai dengan adat istiadat karena Hindu menjiwai adat istiadat.

Demikian agama Hindu dapat diamalkan selama 24 jam setiap hari dengan cara serta bentuk pengamalan yang beraneka ragam. Untuk itu umat Hindu tidak patut memaksakan bentuk pengamalan agama agar seragam dari segi materi maupun bentuk material lainnya, apalagi keseragaman jumlah uang. Namun yang harus sama dan seragam ialah prinsip dasar ajaran agama.

\subsubsection{Implementasi Ajaran Catur Marga Yoga dalam Kehidupan Masyarakat Hindu}

Penerapan catur marga oleh umat Hindu sesungguhnya telah diterapkan secara rutin dalam kehidupannya sehari-hari, termasuk juga oleh umat Hindu yang tinggal di Bali maupun oleh umat Hindu yang tinggal di luar Bali. Banyak cara dan banyak pula jalan yang bisa ditempuh untuk dapat menerapkannya. Sesuai dengan ajaran catur marga bahwa penerapannya disesuaikan dengan kondisi atau keadaan setempat yang berdasarkan atas tradisi, sima, adat-istiadat, drsta, ataupun yang lebih dikenal di Bali yakni desa kala patra atau desa mawa cara.

Inti dan penerapan dan Catur Marga adalah untuk memantapkan mengenai hidup dan kehidupan umat manusia di alam semesta ini, terutama untuk peningkatan, pencerahan, serta memantapkan keyakinan atau kepercayaan (sraddha) dan pengabdian (bhakti) terhadap Tuhan Yang Maha Esa atau Ida Sang Hyang Widhi Wasa. Dengan memahami dan menerapkan ajaran catur marga, maka diharapkan segenap umat Hindu dapat menjadi umat Hindu yang berkualitas, bertanggung jawab, memiliki loyalitas, memiliki dedikasi, memiliki jati diri yang mulia, menjadi umat yang pantas diteladani oleh umat manusia yang lainnya, menjadi umat yang memiliki integritas 
tinggi terhadap kehidupan secara lahir dan batin, dan harapan mulia lainnya guna tercapai kehidupan yang damai, rukun, tenteram, sejahtera, bahagia, dan sebagainya. Jadi dengan penerapan dan ajaran catur marga diharapkan agar kehidupan umat Hindu dan umat manusia pada umumnya menjadi mantap dalam berke-sraddha-an dan berke-bhakti-an kehadapan Tuhan Yang Maha Esa, serta dapat diharmoniskan dengan kehidupan nyata dengan sesama manusia, semua ciptaan Tuhan, dan lingkungan yang damai dan serasi di sekitar kehidupan masingmasing. Tidak ada orang yang menjalankan catur marga itu sendiri-sendiri atau terpisahpisah, karena satu sama lainnya berkaitan. Perincian menjadi empat itu hanyalah untuk mengukur dan memilih 'bobot' jalan yang mana yang bisa diutamakan, sesuai dengan kemampuan masing-masing.

Misalnya seorang yang kurang pengetahuan agama-nya, mungkin dengan mengutamakan bhakti marga dan karma marga saja, ditambah pengetahuan minim (misalnya) rajin melakukan trisandya (termasuk jnyana marga) dan asana (termasuk yoga marga). Bobotnya adalah bhakti marga.Tetapi seorang wiku tentu bobotnya pada jnyana marga dan yoga marga, walaupun bhakti marga yang menjadi dasar dan karma marga tidak juga ditinggalkan.

Kesimpulannya: keempat marga itu dilaksanakan bersama-sama, namun pemilihan mana yang utama tergantung dari kemampuan individu. Inilah salah satu contoh 'kebesaran Agama Hindu' yang membedakannya dengan agama-agama lain yang dogmatis.

1. Mengenai penerapan bhakti marga oleh umat Hindu seperti berikut ini

a. Melaksanakan doa atau puja tri sandhya seçara rutin setiap hari;

b. Menghaturkan banten saiban atau jotan/ngejot atau yajnasesa;

c. Berbakti kehadapan Tuhan Yang Maha Esa beserta semua manifestasi-Nya;

d. Berbakti kehadapan Leluhur;

e. Berbakti kehadapan para pahlawan pejuang bangsa;

f. Melaksanakan upacara dewa yajna (piodalan/puja wali, saraswati, pagerwesi, galungan, kuningan, nyepi, siwaratri, purnama, tilem, tumpek landep, tumpek wariga, tumpek krulut, tumpek wayang dan lain-lainnya);

g. Melaksanakan upacara manusia yajna (magedong-gedongan, 
dapetan, kepus puser, macolongan, tigang sasihin, ngotonin, munggah deha, mapandes, mawiwaha, mawinten, dan sebagainya);

h. Melaksanakan upacara bhuta yajna (masegeh, macaru, tawur, memelihara lingkungan, memelihara hewan, melakukan penghijauan, melestarikan binatang langka, dan sebagainya);

i. Melaksanakan upacara pitra yajna (bhakti kehadapan guru rupaka atau rerama, ngaben, ngerorasin, maligia, mamukur, ngeluwer, berdana punya kepada orang tua, membuat orang tua menjadi hidupnya bahagia dalam kehidupan di alam nyata ini, dan sebagainya);

j. Melaksanakan upacara resi yajna (upacara pariksa, upacara diksa, upacara ngelinggihang veda), berdana punya pada sulinggih atau pandita, berguru pada orang suci, tirtha yatra ke tempat suci bersama sulinggih atau pandita, berguru pada orang suci, sungkem (pranam) pada sulinggih sebagai guru nabe, menerapkan ajaran tri rnam, dan sebagainya
2. Mengenai penerapan karma marga oleh umat Hindu seperti berikut ini

a. Menerapkan filosofi ngayah;

b. Menerapkan filosofi matulungan;

c. Menerapkan filosofi manyama braya;

d. Menerapkan filosofl paras-paros sarpanaya salunglung sabayantaka;

e. Menerapkan fillosofi suka dan duka;

f. Menerapkan filosofi agawe sukaning wong len;

g. Menerapkan filosofi utsaha ta larapana;

h. Menerapkan filosofi makarya;

i. Menerapkan filosofi makarma sane melah;

j. Menerapkan filosofi ala kalawan ayu;

k. Menerapkan filosofi karma phala;

1. Menerapkan filosofi catur paramita;

m. Menerapkan filosofi tri guna;

n. Menerapkan filosofi trikaya parisudha; dan

\section{o. Menerapkan filosofi yama niyama brata dan berbagai ajaran agama Hindu.}

3. Beberapa model atau bentuk nyata dan penerapan jnana marga berikut ini : 
a. Menerapkan ajaran guru dan sisya;

b. Menerapkan ajaran guru bhakti;

c. Menerapkan ajaran guru susrusa;

d. Menerapkan ajaran brahmacari dan ajaran catur guru;

e. Menerapkan ajaran sisya sasana;

f. Menerapkan ajaran resi sasana;

g. Menerapkan ajaran putra sasana;

h. Menerapkan ajaran guru nabe, guru waktra, guru saksi;

i. Menerapkan ajaran catur asrama; dan

j. Menerapkan ajaran dalam wrati sasana, slokantara, sila krama, dan ajaran agama Hindu yang bersumber pada Veda dan susastra Hindu lainnya.

4. Dalam penerapan yoga marga oleh umat Hindu, realitanya seperti berikut :

a. Melaksanakan introspeksi atau pengendalian diri;

b. Menerapkan ajaran tapa, brata, yoga dan samadhi; c. Menerapkan ajaran astangga yoga;

d. Melakukan kerja sama atau relasi yang baik dan terpuji dengan sesama;

e. Menjalin hubungan kemitraan secara terhormat dengan rekanan, lingkungan, dan semua ciptaan Tuhan di alam semesta ini;

f. Membangun pasraman atau paguyuban untuk praktek yoga;

g. Mengelola ashram yang bergerak di bidang pendidikan rohani, agama, spiritual, dan upaya pencerahan diri lahir batin;

h. Menerapkan filosofi mulat sarira;

i. Menerapkan filosofi ngedetin/ngeret indriya;

j. Menerapkan filosfi mauna;

k. Menerapkan filosofi upawasa;

1. Menerapkan filosofi catur brata panyepian, dan

m. Menerapkan filosofi tapasya, pangastawa, dan menerapkan ajaran agama Hindu dengan baik dan benar menuju keluhuran diri sebagai mahluk sosial dan religius.

\section{Kesimpulan}

Demikian uraian singkat tentang Catur Yoga. Semua jalan (marga) dari ke empat 
jalan ini memiliki tujuan yang sama, yaitu untuk menuju kesempurnaan dalam artikesatuan jiwatman dan Paramatman. Jnana Yoga diperuntukkan bagi manusia yang kuat mendalami ilmu pengetahuan, Bhakti Yoga bagi mereka yang kuat dalam cinta-kasih, Karma Yoga bagi mereka yang kuat dalam kerja, dan Raja Yoga bagi mereka yang kuat dalam latihan psikologis. Keempat jalan dan cara diatas semuanya adalah sama, tiap-tiap jalan meletakkandasar dan cara-cara tersendiri. Tidak ada yang lebih tinggi atau lebih rendah,semuanya baik dan utama, tergantung kepribadian, watak, kesanggupan dan bakatmanusia masingmasing. Semuanya akan mencapai tujuannya asal dilakukan dengan pernuh kepercayaan, ketekunan dengan tulus ikhlas, kesujudan, keteguhan iman dan tanpa pamrih. "Dengan jalan bagaimanapun ditempuh oleh manusia ke arahku, semuanya aku terima dan memenuhi keinginan mereka, melalui banyak jalan manusia menuju jalanku, Oh Prtha" (Bhagawad Gita V-2). Catur marga yoga ini merupakan salah satu cara atau jalan terbaik untuk mendekatkan diri kehadapan Ida Sang Hyang Widhi Wasa. Oleh karena itu, kita sebagai umat Hindu hendaknya melaksanakan ajaran Catur Marga Yoga dengan hati yang iklas, sehingga kualitas kehidupan kita akan lebih meningkat dan cenderung kea arah yang lebih baik untuk menuju jalan kebenaran.

\section{DAFTAR PUSTAKA}

Mantra, Ida Bagus. 1970. Bhagawad Gita. Denpasar: Parisada Hindu Dharma Indonesia Provinsi Bali

Pendit, Nyoman S, 1994. Bhagawad Gita. Jakarta: Hanuman Sakti

Pendit, Nyoman S. 1996. Hindu Dharma Abad XXI. Denpasar: Yayasan Dharma Naradha.

Kirit Patel dan Vijay C. Amin. 1999. Karma Yoga. Jakarta: Yayasan Sri Sathya Sai Indonesia.

Praptini, dkk. 2004. Buku Pelajaran Agama Hindu. Surabaya: Paramita

Pidarta, Made. 2005. Hindu Untuk Masyarakat Umum Pada Jaman Pasca Modern. Surabaya: Paramita. 